UDC 341.6

DOI https://doi.org/10.32782/2524-0374/2020-3/110

\title{
«HATE SPEECH» AND THE RIGHT TO FREEDOM OF EXPRESSION: A RATIO AND THE CRITERIA OF DIFFERENTIATION IN THE CONTEXT OF THE DECISIONS OF THE ECHR
}

\author{
«НАTЕ SРЕЕСН» ТА ПРАВО НА СВОБОДУ СЛОВА: \\ СПІВВІДНОШЕННЯ ТА КРИТЕРІЇ РОЗМЕЖУВАННЯ \\ В КОНТЕКСТІ РІШЕНЬ ЄСПЛ
}

\author{
Drongal A.M., 5th Year Student \\ Institute of Prosecution and Criminal Justice \\ of Yaroslav Mudryi National Law University
}

\begin{abstract}
The right to freedom of expression enshrined in article 10 of the European Convention on human rights, in addition to other content, can be applied to information and ideas that can offend, shock or disturb the state, communities, individuals. The definition of «hate speech» given in the Recommendations of the Council of Europe, the term should be understood as such that it covers all forms of expression (text, photo, video, audio, etc.) that disseminate, promote or justify racial hatred, xenophobia, anti-Semitism, aggressive nationalism and ethnocentrism, discrimination and hostility against minorities, migrants and people "of immigrant origin», and also contain the appropriate calls. This approach adheres to the practice of the ECHR, relating to the abuse of the right to freedom of expression «all forms of expression that disseminate, promote or justify hatred based on intolerance (including religious intolerance)». The European Commission against racism and intolerance expressed more specifically: to the spread of enmity and hatred should be attributed propaganda or incitement (or justification) in the form of a slanderous or hateful statements condemning the person or group of persons, as well as any harassment, insults, spreading of negative stereotypes , stigmatization, or threats on the basis of individual characteristics (race, skin color, origin, age, disability, language, religion or belief, gender, gender identity , sexual orientation, etc.).

The information that spreads «hate speech» does not fall under the protection of the 10th article of the European Convention. In cases concerning «hate speech», the ECHR takes into account, where, when, in what socio-political context and with what intention made the statement, its content is of public interest, statements made in the course of political debate, public or private entity, which is its potential impact on the audience, how and how widely it is spread.

Key words: freedom of speech, practice of the ECHR, hate speech, criteria of differentiation, pluralism, the abuse of rights, forms of intolerance.
\end{abstract}

Право на свободу вираження поглядів, закріплене в статті 10 Європейської конвенції з прав людини, крім іншого контенту, можна застосувати до інформації та ідей, які можуть ображати, шокувати чи інакше непокоїти державу, спільноти, окремих людей. Визначення «мови ненависті» дано в Рекомендаціях Ради Європи: термін слід розуміти як такий, що охоплює всі форми вираження (текст, фото, відео, аудіо та ін.), які поширюють, заохочують або виправдовують расову ненависть, ксенофобію, антисемітизм, агресивний націоналізм і етноцентризм, дискримінацію і ворожість по відношенню до меншин, мігрантів і людям «іммігрантського походження», а також містять відповідні заклики. Саме цього підходу дотримується в своїй практиці ЄСПЛ, відносячи до зловживань правом на свободу вираження поглядів «всі форми вираження думки, які поширюють, заохочують або виправдовують ненависть, засновану на нетерпимості (включаючи релігійну нетерпимість)».

Європейська комісія по боротьбі з расизмом і нетерпимістю (далі ЄКБР) висловлюється конкретніше: до поширення ворожнечі і ненависті слід відносити пропаганду або підбурювання (або їх виправдання) - у формі наклепницького або ненависницького висловлювання, який засуджує особу або групу осіб, а також будь-яке переслідування, образу, поширення негативних стереотипів , стигматизацію або загрози на підставі окремих характеристик (раса, колір шкіри, походження, вік, інвалідність, мова, релігія чи переконання, стать, гендерна ідентичність , сексуальна орієнтація та ін.).

Інформація, яку поширює «мова ненависті», не підпадає під захист 10-ї статті Європейської конвенції. При розгляді справ, пов'язаних з «мовою ненависті», ЄСПЛ приймає до уваги, де, коли, в якому суспільно-політичному контексті і з якими намірами зроблено заяву, чи представляє його зміст суспільний інтерес, чи зроблено висловлювання в ході політичних дебатів, публічною або приватною особою, який його потенційний вплив на аудиторію, яким чином і як широко воно поширене.

Ключові слова: свобода слова, практика ЄСПЛ, мова ненависті, критерії розмежування, плюралізм, зловживання правами, фформи нетерпимості.

Statement of the problem. The correct attribution of certain statements to the category of «hate speech» can play an important role in promoting the values of dignity and equality that lie at the basis of international law and human rights. However, this should avoid errors in the interpretation of utterances presented in any form or by any mean( including offensive), as the implementation of the right to freedom of expression enshrined in the Convention. It should also be noted that if a broader interpretation of the concept of «hate speech» right to freedom of speech may considerably be restricted even in cases where the reason for this was not. There is therefore a need to establish clear criteria of demarcation of the right to freedom of speech and «hate speech» on the basis of the case-law of the ECHR and the recommendations of international institutions.

Analysis of recent researches and publications. Research questions the concept of «hate speech» in the context of the right to freedom of expression explored by such scholars as D. Harris, N. O'boyle, K. Worrk [1], M. Rosenfeld [3], Y P. Kuhn [4], A. Brown [7], J. Minocina [8] and others.
The purpose of the article is the relationship of the concept of «hate speech» and the right to freedom of speech. The article will focus on the definition of freedom of speech and will also be the conclusion on the analysis of ECHR judgments in regard to the definition of «hate speech» and a violation of article 10 of the Convention.

Presentation of the basic material. The right to freedom of expression, the researchers believe, is one of the most recognized human rights, it is enshrined in the constitutions of more than $87 \%$ of the countries and appeared in the constitutions of the eighth century.[1] The European Court of human rights (hereinafter European Court), giving the interpretation of article 10 of the European Convention for the protection of human rights and fundamental freedoms ( Convention), which guarantees everyone the «freedom to hold their views, receive and impart information and ideas without interference by bodies of public authorities and regardless of frontiers», is based on the particular value of this right for democracy, emphasizing that freedom of expression 
constitutes one of the fundamental pillars of a democratic society and one of the main conditions of its development, and also an important condition for the realization of abilities of each person. [2]

The European Court adheres to the previously articulated position that freedom of expression under article 10 guaranteed physical and legal entity, and applies to all types of information regardless of the form in which it was expressed, in the form of newspaper articles, scientific publications, music, advertising, the acts of artistic creation. It can be protected even when of a critical nature, which could be considered a criticism as such, which hurt their honor and dignity. The European Court has consistently stood for the protection of journalists and media, if we are talking about criticism of public figures and their policies, so do presidents, governors, deputies, Prime Ministers and important public figures who win in nationa courts lawsuits on protection of honor and dignity, almost no chance to count on the fact that the European Court agrees with the position of the national authorities [3]

The European Court also considers that in the case that defamation directed at any group member of that group does not occur right to file lawsuits on protection of honor and dignity, on the grounds that, for example, referring itself to "team policy», someone thinks that his personal honor and dignity have suffered from accusations that «team policy» destroyed the region's economy. Finally, the European Court recognized the right of journalists to keep secret about the sources of the information received. [1] While the European Court examines whether the alleged breach of the scope of article 10 (i.e., interference) whether it was based on national law, pursued one of the legitimate aims listed in paragraph 2 of article 10, and, finally, was the interference «necessary in a democratic society». The test of «necessity in a democratic society», in turn, requires the Court to determine whether the «interference» was caused by «acute social need», was consistent with a legitimate aim and whether the reasons given by the authorities in his justification, was appropriate and sufficient. Further, to clarify, was a «pressing social need», in all the Affairs that are associated with «hate speech», the European Court, in analyzing the specific circumstances of the case, «will take into account the following elements: the applicant's position, the position of the person against whom the criticism was directed, the subject content of this publication, the characteristics given to controversial statements by national courts, the verbal expression of the statements of the applicant, as well as the punishment that was applied to it» [4].

According to the Recommendations of the Committee of Ministers of the Council of Europe NR (97) on «hate speech» (hate speech) is defined as all forms of expression, which includes the dissemination, provoke, stimulate or justify racial hatred, xenophobia, antisemitism or other forms of hatred based on intolerance, including intolerance in the form of aggressive nationalism or ethnocentrism, discrimination or hostility towards minorities, migrants and people with immigrant roots [5].

General policy recommendation of the European Commission against racism and intolerance contains a more extensive list of criteria, including, among other things, discrimination on the basis of linguistic differences, gender, sexual orientation, and also indicates the possible presence of other factors. [6]

It should be noted that the generally accepted definition of the expressions inciting to hatred does not exist. The case law developed by the Court, allows you to set certain parameters, allowing to characterize hate to exclude her from the legal protection afforded to freedom of expression (article 10) or freedom of Assembly and Association (article 11 of the Convention).

The court noted that the offensive meaning is outside the protection of freedom of speech if it constitutes a «pointless discrediting». At the same time, the use of vulgar phrases in itself is not a decisive factor in assessing the offensiveness of the expression, because it can depend on style. The style is a part of communication as a form of expression and as such protected together with the content of the expressed ideas and information.

With reference to the number of in-house legal positions, the Court explained that incitement to hatred does not necessarily imply an explicit call to violence or other criminal acts. "Attacks on persons committed as a result of insults, incitement to mockery or discreteevent certain population groups may be sufficient for a struggle of power with xenophobic or other discriminatory speech in the face of freedom of expression exercised in an irresponsible,» said the ECHR in its ruling .

As explained by the Court, when assessing specific cases of «interference» in the freedom of expression should take into account different factors. Among them, in particular, the context in which the contested statements; their nature and wording; the ability to lead to harmful effects; themselves the consequences and the reasons given by the domestic courts to justify such interference; whether the statements were made amid a tense political or social background. In addition, you should take into account the fact whether the statements are evaluated in their immediate or broad context, be considered as a direct or indirect call to violence or as an excuse to violence, hatred or intolerance. Thus, the Court emphasized that the interaction of different factors, not any single of them, determines the outcome of a particular case [1].

With the spread of the ideology of tolerance, policy of multiculturalism, the idea of «reverse discrimination» «hate speech» is increasingly the focus of social and humanitarian studies. Most modern research is conducted in line with the psychological, linguistic, legal and sociological approaches.

In the psychological approach, the emphasis is on the features of the perception of hate speech, the analysis of such phenomena as stereotyping of thinking, social expectations, manipulation, persuasion and compulsion.

The linguistic approach aims to study the textual (lexical, morphological, stylistic) means of expression of hate language in this approach of «hate speech» is understood primarily as «linguistically expressed intolerance».

The legal approach focuses on the legal aspects of the identification of "hate speech», the application of sanctions for its use, the degree of objectivity of the forensic linguistic examination.

Finally, under the sociological approach examines not only the frequency and context of use «hate speech» in the public space, but also social causes and conditions conducive to its spread, especially conflicting discourses [7].

A specific practice of the analysis of hate speech can be illustrated with case practice of the European court, which dealt with:

- incitement to hatred on racial grounds (the Decision of the Grand chamber of the European court on the case "Aksu (Aksu) V. Turkey» dated March 15, 2012, decision of the European court in the case of «Feret (Feret) V. Belgium» dated July 16, 2009, decision of the European court in the case of «Leroy (Leroy) V. France» dated October 2, 2008)

- incitement to hatred on grounds of sexual orientation (judgment in the case of «Wigeland and others (Vejdeland and Others) against Sweden» dated February 9, 2012). It should be noted that the European court stresses that discrimination based on sexual orientation is as serious as discrimination based on «racial or ethnic characteristics or color of their skin»;

- incitement to religious hatred (decision of the European court in the case of «Paul Ivanov (Pavel Ivanov) against the Russian Federation» dated February 20, 2007, Judgment of the European court in the case of «mark Anthony Norwood (Norwood Mark Anthony) V. the United Kingdom» dated 
November 16, 2004, and the decision of the European court in the case of "Organization Hizb ut-Tahrir» and other (Hizb ut-Tahrir and Others) against Germany,» 12 June 2012);

- denial of historical facts (decision of the European court in the case of «Garod (Garaudy) V. France» dated 24 June 2003, the decision in the case of «Leide and Zorn (Lehideux and Isorni) V. France» dated 23 September 1998);

- statements based on totalitarian doctrine Islamic fundamentalism (the Decision of the Grand chamber of the European court in the case of «welfare Party and others (Refah Partisi (the Welfare Party)) V. Turkey» dated 13 February 2003, (neo) Nazism (the decision of the Commission on human rights on the case «of the Communist party of Germany, Max Reiman, and Walter fish (German Communist Party, Max Reimann and Walter Fisch) against the Federal Republic of Germany» from July 20, 1957, the decision of the Commission on human rights on the case «BH, MW, HP and GK (BH, MW, HP and GK) V. Austria dated 12 October 1989, nationalism (decision of the European court in the case of "Company Media FM Reha radio Lets Hizmetler ink. "(Medya FM Reha Radyo ve Iletisim Hizmetleri A. S.) V. Turkey» dated 14 November 2006);

- political speeches (the decision in the case of «Temel Faruk (Faruk indir, antikor) V. Turkey» dated February 1, 2011, decision in the case "Oleg Mondragon (Otegi Mondragon) Spain dated March 15, 2011, decision of the European court in the case of «Erbakan (Erbakan) V. Turkey» dated July 6, 2006);

- the anti-constitutional speeches and inciting ethnic hatred (the decision of the European court in the case of «Beler and others (Beleri and Others) vs. Albania» on May 10, 2016, decision of the European court in the case of «Dink (Dink) V. Turkey on 14 September 2010, the Decision in the case «Association of citizens Radko and Paunkovski (Association of Citizens Radko and Paunkovski) against Macedonia» from 15 January 2009 p.,.

- «hate speech» on the Internet: website liability for user comments (Decision of the Grand chamber of the European court on business «the Company of as Delfi (Delfi AS) against Estonia from June 16, 2015) [8]

Analysis of precedents of European court allows you to trace a certain logic in adjudicating cases of incitement to hatred and dissemination of hate speech. Thus, in the practice of the European court is a clear demarcation between the right to freedom of expression and serious provoking extremism or publishing shocking and offensive language and materials. In this case, the European court stresses the special responsibility of journalists and politicians in this context. One of the key criteria is to support the debate and provide a full range of opinions, including statements of the radical wing in the presence of adequate reasoning and lack of direct incitement to violence (the "Gunduz V. Turkey»). In the context of support for the democratic debate, the European court noted certain value of work, which challenged an unambiguous assessment of certain historical events, however, condemns the denial of historically established facts of tragedies such as the Holocaust ( Gerd Hosk V. Austria»). This should take into account the possible contradictions in such matters relating to the national context (including the decisions of the courts on the domestic level) and the presence or absence of international recognition of the fact, for example, genocide in the relations between Armenia and Turkey, Serbia and Bosnia and Herzegovina and other [8].

Regarding the methods of combating hate speech, the European Commission against racism has expressed its opinion with which we agree.

Knowing about the dangerous link between incitement to hatred and violence, ECRI always believed that a criminal prohibition is needed when the incitement to hatred publicly incites violence against individuals or groups of people. At the same time, criminal sanctions should be used as a last resort, and it is necessary to strike a balance between combating incitement to hatred, on the one hand, and the protection of freedom of speech on the other. Any restrictions on incitement to hatred should not be used incorrectly, to silence minorities and to suppress criticism of official policy, political opposition or religious beliefs.

In many cases ECRI found that an effective approach to solving the problem of «hate speech» are self-regulation by public and private institutions, media and Internet industry, for example, the adoption of codes of conduct, accompanied by sanctions for non-compliance. Education and critical thinking are also equally important in the fight against misperceptions and misinformation that are the basis of «hate speech». So ECRI believes that effective measures to counter the use of «hate speech» requires raising public awareness of the importance of respecting pluralism and the dangers associated with «hate speech».

Underestimation of «hate speech» and hate-motivated violence is another sad feature of these two phenomena. Victims rarely report the incidents to authorities for fear of retaliation, or frivolous attitude to them or due to the fact that they do not trust the justice system. This contributes to the lack of data that makes it difficult to quantify the extent of the problem and take effective measures to address it. ECRI encourages States to provide practical support to those who are targeted by hate speech and violence: they must be informed of their rights to reparation through administrative, civil and criminal proceedings, and they should be encouraged to inform the authorities and to legal and psychological assistance [9].

Conclusion. The main problems that arise in the cases of using «hate speech» is the lack of generally accepted concepts concerning the definition of what is attributed to her and maintain a balance between «hate speech» and freedom of expression.

The European court of human rights does not have a unified approach in cases involving «hate speech»:

- there is no single legislative or test the definition of «hate speech» or a specific test (criteria) that determine it;

- there is no common approach to dealing with such cases, so each case is considered individually, which gives rise to inaccuracy in the precedents;

In most cases, the case of «hate speech» are considered the ECHR through the prism of articles 10 («Freedom of expression») and article 17 («Prohibition of abuse of rights») of the Convention. That is, the ECHR considers and decides what restrictions and sanctions are necessary in a democratic society as opposed to total freedom of speech, and isn't the use of «hate speech» abuse of rights by the applicant.

\section{REFERENCES}

1. Law of the European Convention on human rights / Harris, O'Boyle and Worbrik; [Ed. from English. Vlasin V. A. and others]. - Of Sciences. ed., 2nd edition. - M .: The development of legal systems, 2018. - 1432 S.

2. Observer and Guardian v. the United Kingdom. Application no. 13585/88. Judgment of 26 November 1991. Para 59// URL: http: //hudoc. echr.coe.int/eng?i=001-57705.

3. Rosenfeld M. Hate Speech in Constitutional Jurisprudence. A Comparative Analysis // Herz M., Molnar P., editors. The Content and the Context of Hate Speech. New York: Cambridge University Press, 2012. G. 242-289.

4. Reforming the Approach to Racial and Religious Hate Speech Under Article 10 of the European Convention on Human Rights // Philippe Yves Kuhn. Human Rights Law Review, Volume 19, Issue 1, February 2019, Pages 119-147,. URL: https://doi.org/10.1093/hrlr/ngz001 
5. Recommendation N. R (97) 20 of the Committee of Ministers of the Council of Europe States parties to «Incitement of hatred» // URL: http://zakon5.rada.gov.ua/laws/show/994_093

6. ECRI General Policy Recommendation No. 15 - adopted on 8 December 2015 // URL: https://www.coe.int/en/web/european-commissionagainst-racism-and-intolerance/recommendation-no.15

7. Brown A. What is hate speech? Part 1: the myth of hate // Law and Philosophy. 2017. Vol. 36, issue 4. Pp. 419-468. URL: https://www. researchgate.net/publication/315473313_What_is_hate_speech_Part_1_The_Myth_of_Hate

8. Hate speech - opening Pandora's box / $\bar{Y}$. Minochkina // Precedents of the European court. - 2016 . - No. 10. — P. 4-14. URL: https:// rucont.ru/efd/569890

9. ECRI - Hate speech and violence // URL: https://www.coe.int/en/web/european-commission-against-racism-and-intolerance/hate-speechand-violence 